\title{
Synthesis and Diels-Alder Reactions of 1,2-Dimethylene- and 1,2,9,10- Tetramethylene[2.2]paracyclophane: New Routes to Bridge-Anellated [2.2]Paracyclophanedienes ${ }^{4 / 2}$
}

\author{
Burkhard König and Armin de Meijere* \\ Institut für Organische Chemie der Universität Göttingen, \\ Tammannstraße 2, W-3400 Göttingen, F.R.G. \\ Received January 28, 1992
}

Key Words: Bisdienes / Diels-Alder reaction with $p$-benzoquinone / p-Cyclophanes, bridge-anellated

The title compounds 8 and 1 have been synthesized in three steps each from 1,2-dibromo[2,2]paracyclophan-1-ene (2) and 1,2, 9,10-tetrabromo[2.2] paracyclophane-1,9-diene (4), respectively. Copper-mediated coupling of vinyl bromides 2 and 4 with methyl- and phenylmagnesium bromide gives substituted [2.2]paracyclophanes $\mathbf{3}-\mathbf{C H}_{3}, \mathbf{3 - P h}, \mathbf{5 - \mathbf { C H } _ { 3 }}$ and $\mathbf{5 - P h}$ in good yields. The high reactivity of the [2.2]paracyclophane-1,2-dimethylene moieties in 8 and 1 in Diels-Alder reactions has been verified in cycloadditions with $p$-benzoquinone to give 10 and 13 and with naphthalene 1,4-endoxide to yield 12.
Although extremely well-established, the Diels-Alder reaction has been used for a new type of application in recent years: Suitable bis-dienes and bis-dienophiles react in repetitive Diels-Alder fashion to give linear polymers of medium to high molecular weights ${ }^{[1]}$. Because of secondary stereochemical effects, however, only a few precise geometries of the connecting six-membered rings have been realized so far. The physical properties of linear ladder-type polymers are expected to be unusual ${ }^{[2]}$, and they should greatly depend on the properties of the monomers. Inflexibility and strain are attributes of the [2.2]paracyclophane skeleton ${ }^{[3]}$. These could be incorporated into a polymer structure by the repetitive Diels-Alder reaction, if a suitable bifunctionally substituted derivative like 1,2,9,10-tetramethylene[2.2] paracyclophane (1) were available. This communication deals with the cuprous iodide-catalyzed coupling of 1,2-dibromo[2.2] paracyclophan-1-ene (2) and 1,2,9,10-tetrabromo[2.2] paracyclophane-1,9-diene (4) with Grignard reagents of give precursors to phenanthrene-anellated compounds 6,7 as well as 1,2-dimethylene[2.2]paracyclophane $(8)$ and the tetramethylene derivative 1 . Model reactions of $\mathbf{8}$ and $\mathbf{1}$ are included, repetitive DielsAlder reactions of 1 toward polymers will be reported in a forth coming paper ${ }^{[4]}$.

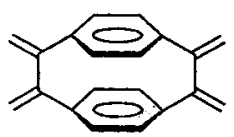

1

Dibromide $2^{[5,6]}$ and tetrabromide $4^{[6]}$ are accessible in reasonably large quantities from [2.2] paracyclophane by a sequence of photochemical bromination, elimination of hydrogen bromide, addition of bromine, and repeated dehydrobromination ${ }^{[6,7]}$. The carbon skeleton of 1 ought to be assembled by replacing all four bromine atoms in 4 by methyl groups. Although there are literature reports on the conversion of vinyl halides to allylic systems via organometallics, for cases of 1,2-dihaloalkenes elimination has been observed exclusively ${ }^{[8]}$.

Reaction of 2 and $\mathbf{4}$ with methylmagnesium bromide in the presence of 30 mol- \% of cuprous iodide yielded 1,2dimethyl[2.2] paracyclophan-1-ene $\left(\mathbf{3}-\mathbf{C H}_{3}\right)$ and $1,2,9,10-$

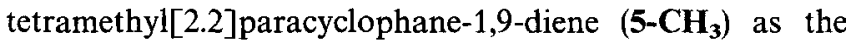
major products ( 80 and $65 \%$, respectively). Mechanistically these reactions might proceed by halogen-metal exchange, elimination of magnesium bromide, addition of a second equivalent of methylmagnesium bromide to the liberated strained alkyne ${ }^{[9]}$, and copper-induced coupling of the resulting vinyl Grignard reagent with methylmagnesium bromide ${ }^{[10]}$.

Scheme 1

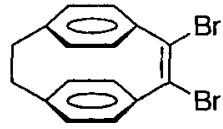

2

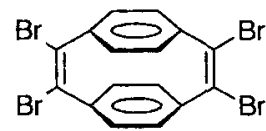

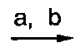

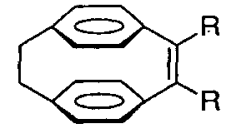

3-R

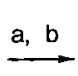

5-R

$$
\mathrm{R}=\mathrm{Me}, \mathrm{Ph}, \mathrm{CH}_{2} \mathrm{Br}
$$

a: $\mathrm{RMgBr}$, Cul, THF, $-78^{\circ} \mathrm{C}$ to room temp. $-\mathrm{b}: \mathrm{Br}_{2}, \mathrm{CH}_{2} \mathrm{Cl}_{2},-15^{\circ} \mathrm{C}$.

The reaction was extended to phenylmagnesium bromide to afford 1,2-diphenyl[2.2] paracyclophan-1-ene (3-Ph) 
$(66 \%)$ and 1,2,9,10-tetraphenyl[2.2]paracyclophane-1,9diene (5-Ph) (25\%); the latter, in close analogy to literature procedures, gave bisphenanthreno[2.2]paracyclophane (7) by oxidative photocyclization ${ }^{[11]}$. Similarly, 3-PH could be photocyclized and oxidized to 1,2-phenanthreno[2.2]paracyclophan-1-ene (6). This approach to phenanthrenobridged [2.2]paracyclophanes complements that reported by Hopf et al. ${ }^{[12]}$.

Scheme 2

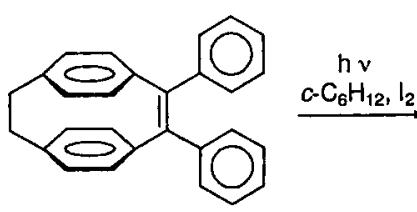

3-Ph

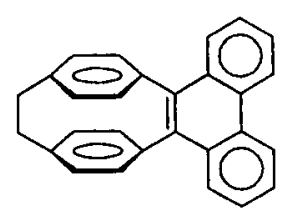

5-Ph

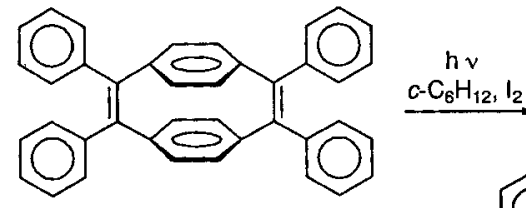

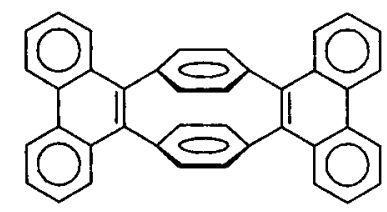

7
By treating a solution of $3-\mathrm{CH}_{3}$ at $-15^{\circ} \mathrm{C}$ with 2 equiv. of bromine, dibromide $3-\mathrm{CH}_{2} \mathrm{Br}$ was obtained in good yield $(68 \%)$. This transformation probably occurred by addition of bromine to the double bond, twofold dehydrobromination to diene 8 , followed by 1,4 -addition of bromine. It was not possible to terminate the reaction at the intermediate target diene 8 . In an analogous manner, $5-\mathrm{CH}_{2} \mathrm{Br}$ was obtained by starting with $\mathbf{5}-\mathbf{C H}_{3}$.

The conversion of $5-\mathrm{CH}_{2} \mathrm{Br}$ and $3-\mathrm{CH}_{2} \mathrm{Br}$ to the target dienes 1 and 8 is easily performed by elimination with activated zinc ${ }^{[13]}$ promoted by ultrasound ${ }^{[14]}$.

Scheme 3

3-Me $\longrightarrow$
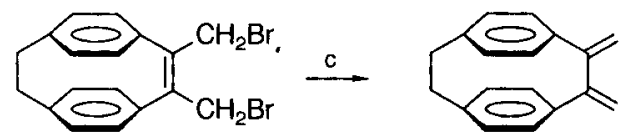

3- $\mathrm{CH}_{2} \mathrm{Br}$

8

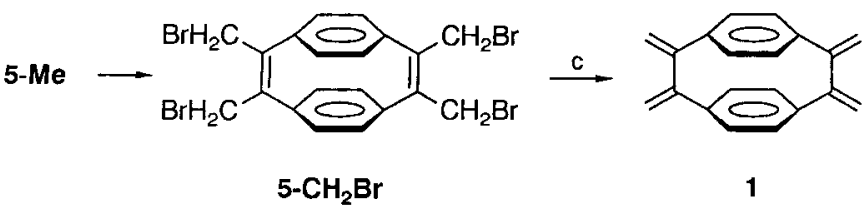

c: $\mathrm{Zn}^{*}$ (activated), dioxane, ultrasound, room temp.

1 and $8^{[15]}$ are stable crystalline compounds, which can be stored as solids in a refrigerator $\left(+6^{\circ} \mathrm{C}\right)$ for months. In solution and exposed to air these compounds slowly decompose.
The Diels-Alder reactivities of 1 and $\mathbf{8}^{[15]}$ were tested in reactions with $p$-benzoquinone (9) and naphthalene 1,4-endoxide (11). Upon heating a mixture of 8 and excess 9 in 1,2-dichlorobenzene to $140^{\circ} \mathrm{C}$ a Diels-Alder adduct was formed. Treatment of the reaction mixture with dichlorodicycano-p-benzoquinone (DDQ) led to 1,2(6,7)-naphthoquinono[2.2] paracyclophan-1-ene (10). Under similar conditions the addition of $\mathbf{8}$ to $\mathbf{1 1}$ afforded the cycloadduct $\mathbf{1 2}$ in high yield. The reaction of two equivalents 8 with $p$ benzoquinone (9) followed by dehydrogenation yielded the "twin-phane" 13.

Scheme 4<smiles>O=C1C=CC(=O)C=C1</smiles>

9

$8+$

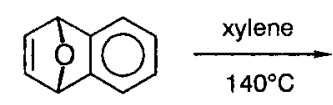
11<smiles>O=C1C=CC(=O)c2cc3c(cc21)CCc1ccc-3cc1</smiles>

10

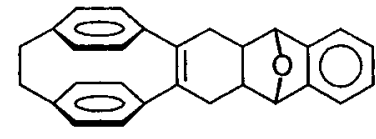

12
$2 \times 8+$

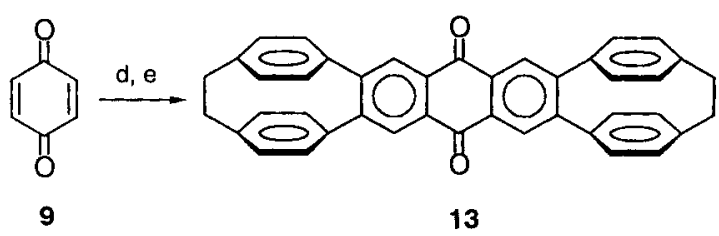

d: Dichlorobenzene, $140^{\circ} \mathrm{C} .-\mathrm{e}: \mathrm{CHCl}_{3}, \mathrm{DDQ}, 50^{\circ} \mathrm{C}$

More extended systems generated by Diels-Alder reactions of bifunctional bisdiene 1 with 9 were completely insoluble in organic solvents and could not be fully characterized by spectroscopic techniques. Only field desorption mass spectrometry and IR spectroscopy can give a hint to their structure. In order to be able to characterize oligomeric and polymeric products with repeating [2.2]paracyclophane units, one definitely needs intermediate chain substituents $\left(\mathrm{C}_{5}\right.$ to $\left.\mathrm{C}_{8}\right)$ in the reacting monomers to increase solubility ${ }^{[\mathrm{b}, 4]}$.

This work was supported by the Volkswagen-Stiftung, the Deutsche Forschungsgemeinschaft, the Fonds der Chemischen Industrie, BASF AG, Hoechst AG, Bayer AG, and Degussa AG. B. K. thanks the Studienstiftung des Deutschen Volkes for a doctoral fellowship.

\section{Experimental}

${ }^{1} \mathrm{H}$ NMR: Bruker WM 250 (250 MHz); $\delta=0$ for tetramethylsilane as internal standard, $\delta=7.26$ for chloroform. $-{ }^{13} \mathrm{C}$ NMR: Bruker WM $250(63 \mathrm{MHz}) ; \delta=77$ for $\mathrm{CDCl}_{3}$; assignments were aided by the measurement of DEPT spectra, + designates primary and tertiary, - secondary and $\mathrm{C}_{\text {quat }}$ quaternary carbon atoms. IR: Perkin-Elmer 297 and 399. - MS: Varian MAT CH7 $(70 \mathrm{eV})$. - Melting points: Electrothermal melting point apparatus, uncor- 
rected. - Column chromatography (CC): Merck silica gel 60, 70-230 mesh. - TLC: Silica gel on aluminum sheets (Merck $\left.F_{254}\right)$.

1,2-Dimethyl 2.2] paracyclophan-1-ene (3-CH3): To a mixture of $750 \mathrm{mg}$ ( $2.1 \mathrm{mmol})$ of 2 and $706 \mathrm{mg}(3.7 \mathrm{mmol})$ of copper(I) iodide in $50 \mathrm{ml}$ of THF was added dropwise at $-78^{\circ} \mathrm{C}$ under $\mathrm{N}_{2}$ and with stirring $4.75 \mathrm{ml}(12.4 \mathrm{mmol})$ of methylmagnesium bromide $(2.6 \mathrm{M}$ solution in ether). The reaction mixture was allowed to warm up to room temp., stirred for an additional $6 \mathrm{~h}$, mixed with $2 \mathrm{ml}$ of methanol, diluted with $200 \mathrm{ml}$ of dichloromethane, and washed with three $100-\mathrm{ml}$ portions of water. The organic layer was dried with $\mathrm{MgSO}_{4}$, filtered, and the solvent evaporated in vacuo. The solid residue was chromatographed over $20 \mathrm{~g}$ silica gel [petroleum ether $\left.\left(60-80^{\circ} \mathrm{C}\right), R_{\mathrm{f}}=0.24\right]$ and recrystallized from hexane to yield $385 \mathrm{mg}(80 \%)$ of $3-\mathrm{CH}_{3}$ as a white solid, m.p. $186^{\circ} \mathrm{C}$. - IR (KBr): $\tilde{v}=3009 \mathrm{~cm}^{-1}, 2948,1584,1091 .{ }^{1} \mathrm{H}$ NMR $\left(\mathrm{CDCl}_{3}\right): \delta=2.22$ $\left(\mathrm{s}, 6 \mathrm{H}, \mathrm{CH}_{3}\right), 3.01[\mathrm{~s}, 4 \mathrm{H}, 9(10)-\mathrm{H}], 6.39\left(\mathrm{AB}\right.$ system, $\delta_{\mathrm{A}}=6.36$, $\left.\delta_{\mathrm{B}}=6.43,{ }^{3} \mathrm{~J}=8 \mathrm{~Hz}, 8 \mathrm{H}\right) \cdot-{ }^{13} \mathrm{C} \mathrm{NMR}\left(\mathrm{CDCl}_{3}\right): \delta=18.73(+$, $\left.\mathrm{CH}_{3}\right), 34.70$ [-, C-9(10)], 131.02 and $132.00(+), 138.02$ and 144.09 $\left(\mathrm{C}_{\text {quat }}\right) .-\mathrm{MS}(70 \mathrm{eV}): m / z(\%)=234(85)\left[\mathrm{M}^{+}\right], 219(100)\left[\mathrm{M}^{+}\right.$ $\left.-\mathrm{CH}_{3}\right]$.

$$
\mathrm{C}_{18} \mathrm{H}_{18} \quad \text { Calcd. } 234.1409 \text { Found 234.1396 (MS) }
$$

1,2,9,10-Tetramethyl (2.2]paracyclophane-1,9-diene (5-CH3): To a mixture of $1.00 \mathrm{~g}(1.923 \mathrm{mmol})$ of 4 and $1.45 \mathrm{~g}$ of copper(I) iodide in $60 \mathrm{ml}$ of THF, kept at $-78^{\circ} \mathrm{C}$, was added with stirring $9 \mathrm{ml}$ (23.4 mmol) of methylmagnesium bromide ( $2.6 \mathrm{M}$ solution in ether). The mixture was allowed to warm up to room temp. and was sonicated ${ }^{[14]}$ for $16 \mathrm{~h}$. After the addition of $2 \mathrm{ml}$ of methanol the reaction mixture was diluted with $300 \mathrm{ml}$ of dichloromethane, washed with water $(3 \times 100 \mathrm{ml})$, dried with $\mathrm{MgSO}_{4}$, filtered, and the filtrate was evaporated to dryness in vacuo. Chromatography over $30 \mathrm{~g}$ of silica gel [petroleum ether $\left(60-80^{\circ} \mathrm{C}\right), R_{\mathrm{f}}=0.35$ ] yielded $323 \mathrm{mg}(65 \%)$ of $\mathbf{5}-\mathbf{C H}_{3}$, white solid, m.p. $181^{\circ} \mathrm{C}$. - IR $(\mathrm{KBr}): \tilde{\mathrm{v}}=3051 \mathrm{~cm}^{-1}, 2980,2902,1436,732 .-{ }^{1} \mathrm{H}$ NMR $\left(\mathrm{CDCl}_{3}\right)$ : $\delta=2.23\left(\mathrm{~s}, 12 \mathrm{H}, \mathrm{CH}_{3}\right), 6.45(\mathrm{~s}, 8 \mathrm{H}) .-{ }^{13} \mathrm{C} \mathrm{NMR}\left(\mathrm{CDCl}_{3}\right): \delta=$ $18.47\left(+, \mathrm{CH}_{3}\right), 129.88(+), 137.05\left(\mathrm{C}_{\text {quat }}\right), 143.36\left(\mathrm{C}_{\text {quat }}\right) .-\mathrm{MS}$ $(70 \mathrm{eV}): m / z(\%)=260(100)\left[\mathrm{M}^{+}\right], 245(29)\left[\mathrm{M}^{+}-\mathrm{CH}_{3}\right], 230$ (62) $\left[\mathrm{M}^{+}-2 \mathrm{CH}_{3}\right], 215(42)\left[\mathrm{M}^{+}-3 \mathrm{CH}_{3}\right]$.

$$
\mathrm{C}_{20} \mathrm{H}_{20} \text { Calcd. 260.1565 Found 260.1565 (MS) }
$$

1,2-Diphenyl/2.2]paracyclophan-1-ene (3-Ph): To a mixture of $300 \mathrm{mg}(0.82 \mathrm{mmol})$ of 2 and $201 \mathrm{mg}(1.0 \mathrm{mmol})$ of copper(I) iodide in $50 \mathrm{ml}$ of THF was added with stirring $7 \mathrm{ml}(3.5 \mathrm{mmol})$ of phenylmagnesium bromide $\left(0.5 \mathrm{M}\right.$ solution in ether) at $-78^{\circ} \mathrm{C}$. After warming up to room temp., the mixture was stirred for an additional $12 \mathrm{~h}$. Workup was performed as described for $\mathbf{3}-\mathbf{C H}_{\mathbf{3}}$, and chromatography over $50 \mathrm{~g}$ of silica gel [petroleum ether $\left(60-80^{\circ} \mathrm{C}\right) /$ dichloromethane, $\left.8: 2\right]$ yielded three fractions: $\mathrm{I}\left(R_{\mathrm{f}}=\right.$ $0.9)$ : biphenyl, not isolated. - II $\left(R_{\mathrm{f}}=0.2\right): 40 \mathrm{mg}(17 \%)$ of 1 phenyl[2.2]paracyclophan-1-ene, m.p. $184^{\circ} \mathrm{C}$. $-\mathrm{IR}(\mathrm{KBr}): \tilde{\mathrm{v}}=$ $3012 \mathrm{~cm}^{-1}, 2946,1495,1096 .-{ }^{1} \mathrm{H}$ NMR $\left(\mathrm{CDCl}_{3}\right): \delta=3.08[\mathrm{~s}$, $4 \mathrm{H}, 9(10)$ - $\mathrm{H}], 6.53\left(\mathrm{AB}\right.$ system, $\delta_{\mathrm{A}}=6.51, \delta_{\mathrm{B}}=6.54,{ }^{3} \mathrm{~J}=8.0 \mathrm{~Hz}$, $8 \mathrm{H}$, phanarene $\mathrm{H}), 7.37(\mathrm{~m}, 3 \mathrm{H}), 7.75(\mathrm{~m}, 3 \mathrm{H}) .-{ }^{13} \mathrm{C} \mathrm{NMR}\left(\mathrm{CDCl}_{3}\right)$ : $\delta=34.80(-), 34.85(-), 126.53(+), 127.85(+), 128.56(+), 130.63$ $(+), 131.80(+), 132.27(+), 132.59(+), 132.60(+), 138.44\left(C_{\text {quat }}\right)$, $138.90\left(\mathrm{C}_{\text {qual }}\right), 139.08\left(\mathrm{C}_{\text {qual }}\right), 139.17\left(\mathrm{C}_{\text {quat }}\right) .-\operatorname{MS}(70 \mathrm{eV}): m / z(\%)$ $=282(100)\left[\mathrm{M}^{+}\right]$.

$\mathrm{C}_{22} \mathrm{H}_{18}$ (282.4) Calcd. C $93.62 \mathrm{H} 6.38$ Found C $93.76 \mathrm{H} 6.43$

III $\left(R_{\mathrm{f}}=0.1\right): 195 \mathrm{mg}(66 \%)$ of 3-Ph, white solid, m.p. $225^{\circ} \mathrm{C}$. IR (KBr): $\tilde{v}=3020 \mathrm{~cm}^{-1}, 2850,1494,1093,747 .-{ }^{1} \mathrm{H}$ NMR $\left(\mathrm{CDCl}_{3}\right): \delta=3.07[\mathrm{~s}, 4 \mathrm{H}, 9(10)-\mathrm{H}], 6.58\left(\mathrm{AB}\right.$ system, $\delta_{\mathrm{A}}=6.56$, $\delta_{\mathrm{B}}=6.60,{ }^{3} \mathrm{~J}=9 \mathrm{~Hz}, 8 \mathrm{H}$, phanarene $\left.\mathrm{H}\right), 7.13(\mathrm{~m}, 6 \mathrm{H}$, phenyl $\mathrm{H})$, $7.35(\mathrm{~m}, 4 \mathrm{H}$, phenyl $\mathrm{H}) .-{ }^{13} \mathrm{C} \mathrm{NMR}\left(\mathrm{CDCl}_{3}\right): \delta=34.65[-, \mathrm{C}-$
9(10)], $127.01(+), 128.03(+), 130.09(+), 132.53(+), 132.86(+)$, $138.62\left(\mathrm{C}_{\text {quat }}\right), 139.83\left(\mathrm{C}_{\text {quat }}\right), 142.91\left(\mathrm{C}_{\text {quat }}\right), 144.66\left(\mathrm{C}_{\text {quat }}\right)$ - - MS $(70 \mathrm{eV}): m / z(\%)=358(100)\left[\mathrm{M}^{+}\right]$.

1,2,9,10-Tetraphenyl 2.2 Jparacyclophane-1,9-diene (5-Ph): To $312 \mathrm{mg}$ ( $0.59 \mathrm{mmol})$ of 4 and $272 \mathrm{mg}(1.4 \mathrm{mmol})$ of copper(I) iodide in $40 \mathrm{ml}$ of THF was added at $-78^{\circ} \mathrm{C} 4.7 \mathrm{ml}(4.7 \mathrm{mmol})$ of phenylmagnesium bromide ( $1 \mathrm{M}$ in ether), and the solution was allowed to warm up to room temp. The reaction was completed by sonication for $12 \mathrm{~h}^{[14]}$ at $20^{\circ} \mathrm{C}$. Workup was carried out as described for $\mathbf{5}-\mathbf{C H}_{3}$, and chromatography over $50 \mathrm{~g}$ of silica gel [petroleum ether $\left.\left(60-80^{\circ} \mathrm{C}\right)\right]$ yielded $\mathrm{I}\left(R_{\mathrm{f}}=0.7\right)$ : biphenyl, not isolated. - II $\left(R_{\mathrm{f}}=0.05\right): 76 \mathrm{mg}(25 \%)$ of 5-Ph, m.p. $318^{\circ} \mathrm{C} .-\mathrm{IR}(\mathrm{KBr}): \tilde{v}=$ $3054 \mathrm{~cm}^{-1}, 2963,1493,1096,695 .-{ }^{1} \mathrm{H}$ NMR $\left(\mathrm{CDCl}_{3}\right): \delta=6.83$ $(\mathrm{s}, 8 \mathrm{H}), 7.22(\mathrm{~m}, 12 \mathrm{H}$, phenyl $\mathrm{H}), 7.45(\mathrm{~m}, 8 \mathrm{H}$, phenyl $\mathrm{H}) .-{ }^{13} \mathrm{C}$ $\operatorname{NMR}\left(\mathrm{CDCl}_{3}\right): \delta=127.13(+), 128.03(+), 130.22(+), 131.88(+)$, $139.43\left(\mathrm{C}_{\text {quat }}\right), 143.49\left(\mathrm{C}_{\text {quat }}\right), 144.16\left(\mathrm{C}_{\text {quat }}\right) .-\operatorname{MS}(70 \mathrm{eV}): \mathrm{m} / \mathrm{z}(\%)$ $=508(100)\left[\mathrm{M}^{+}\right]$.

\section{$\mathrm{C}_{40} \mathrm{H}_{28}$ Calcd. 508.2191 Found 508.2203 (MS)}

1,2:9,10-Bis $(9,10)$ phenanthreno[2.27paracyclophane-1,9-diene (7): A solution of $76 \mathrm{mg}(0.15 \mathrm{mmol})$ of $5-\mathrm{Ph}$ and $80 \mathrm{mg}(0.31 \mathrm{mmol})$ of iodine in $550 \mathrm{ml}$ of cyclohexane was irradiated with a $250-\mathrm{W} \mathrm{Hg}$ medium-pressure lamp for $12 \mathrm{~h}$. The solution was concentrated in vacuo, the precipitated product collected by filtration, washed with $10 \mathrm{ml}$ of chloroform and $10 \mathrm{ml}$ of $n$-pentane and dried in vacuo to yield $38 \mathrm{mg}(50 \%)$ of 7, m.p. $>350^{\circ} \mathrm{C}$. - IR $(\mathrm{KBr}): \tilde{v}=3070 \mathrm{~cm}^{-1}$, 1608, 1448, 1055, 759. - ${ }^{1} \mathrm{H}$ NMR $\left(\mathrm{CDCl}_{3}\right): \delta=6.93$ (s, 8H), 7.40 and $7.79(\mathrm{~m}, 10 \mathrm{H}$, phenanthrene $\mathrm{H}), 8.30\left(\mathrm{~d},{ }^{3} J=7.5 \mathrm{~Hz}, 2 \mathrm{H}\right), 8.91$ $\left(\mathrm{d},{ }^{3} J=7.5 \mathrm{~Hz}, 2 \mathrm{H}\right), 9.80(\mathrm{~m}, 2 \mathrm{H}) .-\mathrm{MS}(70 \mathrm{eV}): m / z(\%)=504$ (100) $\left[\mathrm{M}^{+}\right], 252(10)\left[\mathrm{M}^{2+}\right]$.

\section{$\mathrm{C}_{40} \mathrm{H}_{24}$ Calcd. 504.1878 Found 504.1850 (MS)}

1,2(9,10)-Phenanthreno[2.27paracyclophan-1-ene (6): A solution of $80 \mathrm{mg}(0.22 \mathrm{mmol})$ of $3-\mathrm{Ph}$ and $56 \mathrm{mg}(0.22 \mathrm{mmol})$ of iodine in $100 \mathrm{ml}$ of cyclohexane was irradiated in a quartz tube with a 250 W Hg medium-pressure lamp for $4 \mathrm{~h}$. The solvent was removed in vacuo and the residue chromatographed over $50 \mathrm{~g}$ of silica gel [petroleum ether $\left(60-70^{\circ} \mathrm{C}\right) /$ dichloromethane, $\left.1: 1, R_{\mathrm{f}}=0.48\right]$ to yield $61 \mathrm{mg}(78 \%)$ of 6, m.p. $>280^{\circ} \mathrm{C}$. - IR $(\mathrm{KBr}): \tilde{v}=2922 \mathrm{~cm}^{-1}$ 1489, 1179. - ${ }^{1} \mathrm{H}$ NMR $\left(\mathrm{CDCl}_{3}\right): \delta=3.17(\mathrm{~s}, 4 \mathrm{H}), 6.66(\mathrm{~s}, 8 \mathrm{H})$, $7.61(\mathrm{~m}, 4 \mathrm{H}), 8.12\left(\mathrm{~d},{ }^{3} J=9.0 \mathrm{~Hz}, 2 \mathrm{H}\right), 8.79\left(\mathrm{~d},{ }^{3} \mathrm{~J}=9.0 \mathrm{~Hz}, 2 \mathrm{H}\right)$. $-{ }^{13} \mathrm{C} \mathrm{NMR}\left(\mathrm{CDCl}_{3}\right): \delta=34.86(-), 122.67(+), 126.48(+), 126.75$ $(+), 128.66(+), 129.77\left(\mathrm{C}_{\text {quat }}\right), 131.01\left(\mathrm{C}_{\text {quat }}\right), 132.60(+), 132.95(+)$, $138.93\left(\mathrm{C}_{\text {quat }}\right), 139.42\left(\mathrm{C}_{\mathrm{quat}}\right), 141.55\left(\mathrm{C}_{\text {quat }}\right) .-\mathrm{MS}(70 \mathrm{eV}): m / z(\%)$ $=356(100)\left[\mathrm{M}^{+}\right], 178(7)\left[\mathrm{M}^{2+}\right]$.

$$
\mathrm{C}_{28} \mathrm{H}_{20} \text { Calcd. } 356.1565 \text { Found } 356.1581 \text { (MS) }
$$

1,2-Bis (bromomethyl) [2.2]paracyclophan-1-ene (3-CH. $\mathbf{2} \mathbf{B r}): 7 \mathrm{ml}$ $(2.76 \mathrm{mmol})$ of a $2 \%$ solution of bromine in dichloromethane was added dropwise to $308 \mathrm{mg}(1.32 \mathrm{mmol})$ of $\mathbf{3}-\mathbf{C H}_{3}$ in $40 \mathrm{ml}$ of dichloromethane at $-15^{\circ} \mathrm{C}$, and the mixture was stirred for $0.5 \mathrm{~h}$ The organic phase was washed with $20 \mathrm{ml}$ of satd. aqueous sodium thiosulfate and $20 \mathrm{ml}$ of water, dried with $\mathrm{MgSO}_{4}$, filtered, and the solvent was evaporated from the filtrate in vacuo. Chromatography over $50 \mathrm{~g}$ of silica gel (petroleum ether/dichloromethane, 1:1) yielded $350 \mathrm{mg}(68 \%)$ of $3-\mathbf{C H}_{2} \mathbf{B r}$, white solid, m.p. $151^{\circ} \mathrm{C}$. - IR $(\mathrm{KBr}): \tilde{\mathrm{v}}=2925 \mathrm{~cm}^{-1}, 1494,725 .-{ }^{1} \mathrm{H}$ NMR $\left(\mathrm{CDCl}_{3}\right): \delta=3.03$ [s, 4H, 9(10)-H], $4.54(\mathrm{~s}, 4 \mathrm{H}), 6.49(\mathrm{~s}, 8 \mathrm{H}) .-{ }^{13} \mathrm{C}$ NMR $\left(\mathrm{CDCl}_{3}\right)$ : $\delta=29.38(-), 34.73(-), 132.49(+), 138.28\left(\mathrm{C}_{\text {quat }}\right), 139.36\left(\mathrm{C}_{\text {quat }}\right)$, $143.51\left(\mathrm{C}_{\text {quat }}\right)$.

$$
\mathrm{C}_{18} \mathrm{H}_{16} \mathrm{Br}_{2} \quad \text { Calcd. } 389.9619 \text { Found } 389.9622 \text { (MS) }
$$

1,2,9,10-Tetrakis (bromomethyl) /2.2 /paracyclophane-1,9-diene (5$\left.\mathbf{C H}_{2} \mathbf{B r}\right)$ : To $509 \mathrm{mg}(1.96 \mathrm{mmol})$ of $\mathbf{5 - \mathbf { C H } _ { 3 }}$ in $30 \mathrm{ml}$ of dichloromethane was added at $-15^{\circ} \mathrm{C}$ with stirring $20.3 \mathrm{ml}(7.83 \mathrm{mmol})$ of 
a solution of bromine in dichloromethane $(1: 50)$. The reaction mixture was stirred for an additional $2 \mathrm{~h}$. The precipitated product was collected by filtration, washed with $50 \mathrm{ml}$ of chloroform, and dried in vacuo to yield $600 \mathrm{mg}(53 \%)$ of $5-\mathrm{CH}_{2} \mathbf{B r}$ as a white solid, m.p. $>290^{\circ} \mathrm{C}$. - IR $(\mathrm{KBr}): \tilde{v}=2960 \mathrm{~cm}^{-1}, 2360,1489,605 .-{ }^{1} \mathrm{H}$ NMR $\left(\mathrm{CDCl}_{3}\right): \delta=4.55(\mathrm{~s}, 8 \mathrm{H}), 6.64(\mathrm{~s}, 8 \mathrm{H}),-\mathrm{MS}(70 \mathrm{eV}): m / z(\%)=$ $580 / 578 / 576 / 574 / 572(6 / 8 / 100 / 29 / 9)\left[\mathrm{M}^{+}\right], 499 / 497 / 495 / 493(13 / 48 /$ $82 / 15)\left[\mathrm{M}^{+}-\mathrm{Br}\right], 418 / 417 / 416 / 414(8 / 30 / 63 / 5)\left[\mathrm{M}^{+}-2 \mathrm{Br}\right]$, $337 / 335(47 / 50)\left[\mathrm{M}^{+}-3 \mathrm{Br}\right], 256(44)\left[\mathrm{M}^{+}-4 \mathrm{Br}\right]$.

1,2-Dimethylene [2.27paracyclophane (8): After sonication ${ }^{[14]}$ of a mixture of $702 \mathrm{mg}(1.8 \mathrm{mmol})$ of $\mathbf{3}-\mathbf{C H}_{\mathbf{2}} \mathbf{B r}$ and $270 \mathrm{mg}(4.1 \mathrm{mmol})$ of activated zinc ${ }^{[13]}$ in $30 \mathrm{ml}$ of dry 1,4-dioxane for $2 \mathrm{~h}$, the reaction mixture was diluted with $30 \mathrm{ml}$ of ether, filtered to remove unreacted zinc and zinc salts, the filtrate was washed with $50 \mathrm{ml}$ of a satd. aqueous ammonium chloride solution and $50 \mathrm{ml}$ of water, dried with $\mathrm{MgSO}_{4}$, and the solvents were evaporated in vacuo. The solid residue was chromatographed over silica gel [petroleum ether $\left.\left(60-80^{\circ} \mathrm{C}\right), R_{\mathrm{f}}=0.25\right]$ to yield $227 \mathrm{mg}(55 \%)$ of $8, \mathrm{~m} . \mathrm{p} .160^{\circ} \mathrm{C}$ (dec.). - IR (KBr): $\tilde{v}=3010 \mathrm{~cm}^{-1}, 2926,1394,728 .-{ }^{1} \mathrm{H}$ NMR $\left(\mathrm{CDCl}_{3}\right): \delta=3.05[\mathrm{~s}, 4 \mathrm{H}, 9(10)-\mathrm{H}], 5.27\left(\mathrm{~d},{ }^{2} J=1.7 \mathrm{~Hz}, 2 \mathrm{H}\right), 5.66$ $\left(\mathrm{d},{ }^{2} J=1.7 \mathrm{~Hz}, 2 \mathrm{H}\right), 6.49\left(\mathrm{AB}\right.$ system, $\delta_{\mathrm{A}}=6.46, \delta_{\mathrm{B}}=6.53,{ }^{3} \mathrm{~J}=$ $8 \mathrm{~Hz}, 8 \mathrm{H}) .-{ }^{13} \mathrm{C} \mathrm{NMR}\left(\mathrm{CDCl}_{3}\right): \delta=34.58(-), 108.91(-), 132.47$ $(+), 133.39(+), 138.30\left(\mathrm{C}_{\text {quat }}\right), 140.95\left(\mathrm{C}_{\text {qual }}\right), 153.39\left(\mathrm{C}_{\text {quat }}\right) .-\mathrm{MS}$ $(70 \mathrm{eV}): m / z(\%)=232(100)\left[\mathrm{M}^{+}\right]$.

$\mathrm{C}_{18} \mathrm{H}_{16}$ Calcd. 232.1252 Found 232.1252 (MS)

1,2,9,10-Tetramethylene[2.2] paracyclophane (1): A mixture of $200 \mathrm{mg}(0.35 \mathrm{mmol})$ of $5-\mathbf{C H}_{2} \mathbf{B r}$ and $105 \mathrm{mg}(1.6 \mathrm{mmol})$ of activated zinc $^{[13]}$ in $30 \mathrm{ml}$ of freshly distilled 1,4-dioxane was sonicated ${ }^{[14]}$ at room temp. for $12 \mathrm{~h}$. Workup was carried out as described for $\mathbf{8}$, and flash chromatography over $50 \mathrm{~g}$ of silica gel [petroleum ether $\left.\left(60-80^{\circ} \mathrm{C}\right), R_{\mathrm{f}}=0.27\right]$ yielded $82 \mathrm{mg}(92 \%)$ of 1 as a white crystalline solid, m.p. $160^{\circ} \mathrm{C}$ (dec.). - IR (KBr): $\tilde{v}=3085 \mathrm{~cm}^{-1}, 1597$, 1485, 1073, 744. $-{ }^{1} \mathrm{H}$ NMR $\left(\mathrm{CDCl}_{3}\right): \delta=5.40\left(\mathrm{~d},{ }^{2} J=1.7 \mathrm{~Hz}\right.$, $4 \mathrm{H}), 5.71\left(\mathrm{~d},{ }^{2} J=1.7 \mathrm{~Hz}, 4 \mathrm{H}\right), 6.58(\mathrm{~s}, 8 \mathrm{H}) .-{ }^{13} \mathrm{C} \mathrm{NMR}\left(\mathrm{CDCl}_{3}\right)$ : $\delta=109.77(-), 132.45(+), 139.41\left(\mathrm{C}_{\text {quat }}\right), 152.26\left(\mathrm{C}_{\text {quat }}\right) .-\mathrm{MS}(70$ $\mathrm{eV}): m / z(\%)=256(100)\left[\mathrm{M}^{+}\right]$.

\section{$\mathrm{C}_{20} \mathrm{H}_{16}$ (256.3) Calcd. 93.75 H 6.25 Found C $93.69 \mathrm{H} 6.28$}

1,2(6,7) Naphthoquinono[2.2] paracyclophan-1-ene (10): $22 \mathrm{mg}$ $(0.1 \mathrm{mmol})$ of 8 and $210 \mathrm{mg}(0.19 \mathrm{mmol})$ of $p$-benzoquinone (9) were heated in $2 \mathrm{ml}$ of dichlorobenzene at $140^{\circ} \mathrm{C}$ for $4 \mathrm{~h}$. The solvent was removed in vacuo, the residue dissoived in $20 \mathrm{ml}$ of chloroform and the reaction mixture stirred after the addition of $30 \mathrm{mg}(0.13$ $\mathrm{mmol}$ ) of 2,3-dichloro-5,6-dicyano-p-benzoquinone (DDQ) for $12 \mathrm{~h}$ at $50^{\circ} \mathrm{C}$. The solvent was evaporated and the residue subjected to flash chromatography over $50 \mathrm{~g}$ of silica gel (dichloromethane, $\left.R_{\mathrm{f}}=0.3\right)$ yielding $17 \mathrm{mg} \mathrm{(53 \% )}$ of 10 , yellow crystals, m.p. $220^{\circ} \mathrm{C}$. - IR (KBr): $\tilde{v}=2924 \mathrm{~cm}^{-1}, 1670(\mathrm{C}=\mathrm{O}), 1603,804 .-{ }^{1} \mathrm{H}$ NMR $\left(\mathrm{CDCl}_{3}\right): \delta=3.14[\mathrm{~s}, 4 \mathrm{H}, 9(10)-\mathrm{H}], 6.56\left(\mathrm{AB}\right.$ system, $\delta_{\mathrm{A}}=6.52$, $\left.\delta=6.59,{ }^{3} J_{\mathrm{AB}}=8 \mathrm{~Hz}, 8 \mathrm{H}\right), 7.06(\mathrm{~s}, 2 \mathrm{H}), 8.29(\mathrm{~s}, 2 \mathrm{H}) .-{ }^{13} \mathrm{C} \mathrm{NMR}$ $\left(\mathrm{CDCl}_{3}\right): \delta=34.81[-, \mathrm{C}-9(10)], 123.63(+), 130.73\left(\mathrm{C}_{\text {quat }}\right), 131.93$ $(+), 132.58(+), 138.27\left(\mathrm{C}_{\text {quat }}\right), 140.16\left(\mathrm{C}_{\text {quat }}\right), 151.89\left(\mathrm{C}_{\text {quat }}\right), 158.77$ $(+), 185.22\left(\mathrm{C}_{\text {quat }}\right) .-\mathrm{MS}(70 \mathrm{eV}): m / z(\%)=336(100)\left[\mathrm{M}^{+}\right]$.

\section{$\mathrm{C}_{24} \mathrm{H}_{16} \mathrm{O}_{2}$ Calcd. 336.1150 Found 336.1151 (MS)}

2,3: 6,7-Bis ([2.2]paracyclophan-1-eno) anthraquinone (13): A mixture of $50 \mathrm{mg}(0.22 \mathrm{mmol})$ of 8 and $12 \mathrm{mg}(0.12 \mathrm{mmol})$ of 9 was heated in $1 \mathrm{ml}$ of dichlorobenzene at $160^{\circ} \mathrm{C}$ for $8 \mathrm{~h}$. The solvent was removed in vacuo, the residue dissolved in $20 \mathrm{ml}$ of chloroform and the obtained solution stirred with $80 \mathrm{mg}(0.35 \mathrm{mmol})$ of DDQ for $12 \mathrm{~h}$ at $50^{\circ} \mathrm{C}$. The reaction mixture was diluted with $50 \mathrm{ml}$ of chloroform, washed with $50 \mathrm{ml}$ of dil. aqueous sodium hydroxide and $50 \mathrm{ml}$ of water, dried with $\mathrm{MgSO}_{4}$, and concentrated. The residue was subjected to flash chromatography over $30 \mathrm{~g}$ of silica gel with dichloromethane as eluent $\left(R_{\mathrm{f}}=0.05\right)$ yielding $15 \mathrm{mg}(25 \%)$ of 13, m.p. $>300^{\circ} \mathrm{C}$. - IR $(\mathrm{KBr}): \tilde{v}=2971 \mathrm{~cm}^{-1}, 1671(\mathrm{C}=\mathrm{O})$, 1588, 1093. $-{ }^{1} \mathrm{H} \mathrm{NMR}\left(\mathrm{CDCl}_{3}\right): \delta=3.16(\mathrm{~s}, 8 \mathrm{H}), 6.617$ and 6.621 $(\mathrm{s}, 16 \mathrm{H}$, phanarene $\mathrm{H}), 8.57(\mathrm{~s}, 4 \mathrm{H}) .-\mathrm{MS}(70 \mathrm{eV}): m / z(\%)=564$ (100) $\left[\mathrm{M}^{+}\right]$.

$$
\mathrm{C}_{42} \mathrm{H}_{28} \mathrm{O}_{2} \text { Calcd. } 564.20892 \text { Found } 564.20893 \text { (MS) }
$$

$1^{\prime}, 4^{\prime}, 4 a^{\prime}, 9^{\prime}, 10^{\prime}, 10 a^{\prime}-$ Hexahydro- $9^{\prime}, 10^{\prime}$-epoxy-1,2(2,3)-anthraceno[2.2]paracyclophan-1-ene (12): $30 \mathrm{mg}(0.13 \mathrm{mmol})$ of 8 and $18.6 \mathrm{mg}$ $(0.13 \mathrm{mmol})$ of 11 were heated in $2 \mathrm{ml}$ of xylene at $120^{\circ} \mathrm{C}$ for $6 \mathrm{~h}$. The solvent was removed in vacuo and the solid residue washed with $n$-pentane. As verified by the ${ }^{1} \mathrm{H}$ - and ${ }^{13} \mathrm{C}-\mathrm{NMR}$ spectra 12 was the only reaction product. - IR $(\mathrm{KBr}): \tilde{v}=3005 \mathrm{~cm}^{-1}, 2930$, 850, 724, 614. $-{ }^{1} \mathrm{H}$ NMR $\left(\mathrm{CDCl}_{3}\right): \delta=2.28(\mathrm{~m}, 2 \mathrm{H}), 2.70$ and $3.05(\mathrm{~m}, 8 \mathrm{H}), 5.12(\mathrm{~s}, 2 \mathrm{H}), 6.21$ and $6.40(\mathrm{~m}, 8 \mathrm{H}$, phanarene), $7.10-7.30$ (AA'BB' system, $4 \mathrm{H}) .-{ }^{13} \mathrm{C} \mathrm{NMR}\left(\mathrm{CDCl}_{3}\right): \delta=32.62$ $(-), 34.68(-), 43.02(+), 85.18(+), 118.95(+), 126.62(+), 130.79$ $(+), 131.27(+), 131.93(+)$ and $131.96(+), 138.44\left(\mathrm{C}_{\mathrm{quat}}\right), 142.38$ $\left(\mathrm{C}_{\text {quat }}\right), 142.79\left(\mathrm{C}_{\text {quat }}\right), 145.86\left(\mathrm{C}_{\text {quat }}\right) .-\mathrm{MS}(70 \mathrm{eV}): m / z(\%)=376$ (100) $\left[\mathrm{M}^{+}\right], 258 / 118(29 / 28)$ [retro Diels-Alder products].

\section{$\mathrm{C}_{28} \mathrm{H}_{24} \mathrm{O}$ Calcd. 376.1827 Found 376.1817 (MS)}

Dedicated to Professor Hans-Friedrich Grützmacher on the occasion of his 60th birthday.

[1] [1a] J. F. Stoddart, F. H. Kohnke, Angew. Chem. 1987, 99, 941 -943; Angew. Chem. Int. Ed. Engl. 1987, 26, 930; J. F. Stoddart, P. R. Ashton, N. S. Isaacs, F. H. Kohnke, ibid. 1988, 100, 981-983, and 1988, 27, 961. - [1b] J. F. Stoddart, F. H. Kohnke, Angew. Chem. 1989, 101, 1266-1271; Angew. Chem. Int. Ed. Engl. 1989, 28, 1217, 1230; F. H. Kohnke, J. P. Mathias, J. F. Stoddart, Adv. Mater. 1989, 1, 275. - [ic] M. Wagner, W. Wohlfarth, K. Müllen, Chimia 1988, 42, 377-379; M. Pollmann, W. Wohlfarth, K. Müllen, J. Lex, Tetrahedron Lett. 1990, 31, 2701 -2704; U. Scharf, K. Müllen, Synthesis 1992, 23-38, and references cited therein. - [1d] K. Blatter, A. D. Schlüter, Chem. Ber. 1989, 122, $1351-1356$. - ${ }^{1 \text { iel }}$ K. Blatter, A. D. Schlüter, G. Wegner, Macromolecules 1989, 22, 3506-3508. - ${ }^{[1]}$ G. Wegner, K. Blatter, A. D. Schlüter, J. Org. Chem. 1989, 54, 2396-2401; A. D. Schlüter, Adv. Mater. 1991, 3, 282.

${ }^{[2]}$ Cf. W. J. Bailey, Polym. Mater. Sci. Eng. 1989, 60, 400-403; L. Dalton, M. McLean, D. Polis, C. Young, ibid. 1989, 60, 410-414; S. A. Jenekhe, P. O. Johnson, A. K. Agrawal, ibid. 1989, 60, $404-409$, and references cited therein.

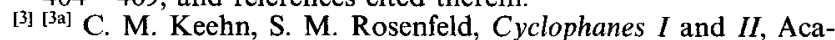
demic Press, New York, 1983. - ${ }^{[26]}$ F. Vögtle, Top. Curr. Chem. $1983,113,115$.

${ }^{[4]}$ B. König, A. D. Schlüter, T. Vogel, A. de Meijere, manuscript in preparation.

${ }^{[5]}$ H. Hopf, M. Psiorz, Chem. Ber. 1986, 119, 1836- 1844.

${ }^{[6]}$ O. Reiser, S. Reichow, A. de Meijere, Angew. Chem. 1987, 99 , 1285-1286; Angew. Chem. Int. Ed. Engl. 1987, 26, 1277-1278. ${ }^{[7]}$ A. de Meijere, O. Reiser, B. König, M. Rabinovitz, J. Heinze, K. Meerholz, J. Am. Chem. Soc. 1992, submitted.

${ }^{[8]}$ G. H. Posner, J. S. Ting, Synth. Commun. 1973, 3, 281 - 285.

${ }^{[9]}$ Cf. ${ }^{[9 a]}$ C. W. Chan, H. N. C. Wong, J. Am. Chem. Soc. 1985, $107,4790-4791$. - ${ }^{[9 b]}$ H. N. C. Wong, C. W. Chan, J. Am. Chem. Soc. 1988, 110, 3790-3794. - ${ }^{\left.{ }^{9 c}\right]}$ See also: A. de Meijere, J. Heinze, K. Meerholz. O. Reiser, B. König, Angew. Chem. 1990, 102, 1443-1445; Angew. Chem. Int. Ed. Engl. 1990, 29, $1418-1419$; ibid. 1991, 103, 1350-1351, and 1991, 30, $1361-1363$

${ }^{[10]}$ Cf. I. P. Beletskaya, J. Organomet. Chem. 1983, 250, 551- 556.

${ }^{[11]}$ T. Sato, S. Shimada, K. Hata, Bull. Chem. Soc. Jpn. 1971, 44 $2484-2490$.

${ }^{[12]}$ H. Hopf, C. Mlynek, J. Org. Chem. 1990, 55, 1361 - 1363.

${ }^{[13]} C f$. M. P. Cava, M. Lukshmikanthan, R. J. Ardecky, F. A. Kerdensky, J. Am. Chem. Soc. 1981, 103, 1992-1996.

${ }^{[14]}$ A commercial ultrasonic laboratory cleaning bath was used (Bandelin, Berlin, Type Sonorex R255).

${ }^{115]}$ Preparation and Diels-Alder reactions of analogous 10,11-dimethylene[3.2]paracyclophane have been reported previously: H. F. Grützmacher, K. Albrecht, Chem. Ber. 1989, 122, $2299-2302$

$[40 / 92]$ 